JAMP: Jurnal Adminitrasi dan Manajemen Pendidikan

Volume 1 Nomor 4 Desember 2018, Hal : 454-466

Tersedia Online di http://journal2.um.ac.id/index.php/jamp/

ISSN 2615-8574 (online)

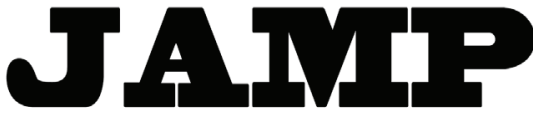

JURNAL ADMINISTRASI DAN MANAJEMEN PENDIDIKAN

\title{
PERBEDAAN MOTIVASI DAN PRESTASI BELAJAR ANTARA PENGURUS HARIAN DAN ANGGOTA UNIT KEGIATAN MAHASISWA (UKM)
}

\author{
Muhammad Ali Yafi Hidayatullah \\ Ali Imron \\ Ibrahim Bafadal \\ yafyafi1177@gmail.com \\ Universitas Negeri Malang, Jalan Semarang No. 5 Malang
}

\begin{abstract}
The purpose of this study was to determine differences in motivation and learning achievement of students who became daily administrators and members of UKM. This study uses a quantitative approach with comparative casual descriptive research design. The instrument used in this study was a questionnaire with Malang State University student respondents. Data analysis techniques used are descriptive analysis techniques and test test techniques. Based on the results of the study it can be concluded that: learning motivation of daily instructors is included in high qualifications; learning motivation of UKM members is included in high qualifications; the level of learning achievement of daily administrators, in academic achievement in the title is very satisfying, in non-academic achievement has a percentage at the National level; the level of learning achievement of UKM members, in academic achievement in honors, in non-academic achievements they have a national level; there is a significant difference in the learning motivation of students who become UKM daily administrators and who are members of UKM; there is no significant difference in the academic learning achievement of students who are UKM administrators and who are members of UKM; there are significant differences in non-academic learning achievement of students who become UKM daily administrators and who are members of UKM.
\end{abstract}

Keywords: Motivation, Learning Achievement, Student Activity Unit

\begin{abstract}
Abstrak: Tujuan penelitian ini adalah untuk mengetahui perbedaan motivasi dan prestasi belajar mahasiswa yang menjadi pengurus harian dan anggota UKM. Penelitian ini memakai pendekatan kuantitatif dengan rancangan penelitian deskriptif kasual komparatif. Instrumen yang digunakan dalam penelitian ini berupa angket dengan responden mahasiswa Universitas Negeri Malang. Teknik analisis data yang digunakan adalah teknik analisis deskriptif dan teknik uji Test. Berdasarkan hasil penelitian dapat disimpulkan bahwa: motivasi belajar penguruh harian termasuk dalam kualifikasi tinggi; motivasi belajar anggota UKM termasuk dalam kualifikasi tinggi; tingkat prestasi belajar pengurus harian, dalam prestasi akademik dalam predikat sangat memuaskan, dalam prestasi non akademik memiliki presentase ditingkat Nasional; tingkat prestasi belajar anggota UKM, dalam prestasi akademik dalam predikat dengan pujian, dalam prestasi non akademik memiliki presentase ditingkat Nasional; terdapat perbedaan yang signifikan motivasi belajar mahasiswa yang menjadi pengurus harian UKM dan yang menjadi anggota UKM; tidak terdapat perbedaan yang signifikan prestasi belajar akademik mahasiswa yang menjadi pengurus harian UKM dan yang menjadi anggota UKM; terdapat perbedaan yang signifikan prestasi belajar non akademik mahasiswa yang mennjadi pengurus harian UKM dan yang menjadi anggota UKM.
\end{abstract}

Kata kunci: Motivasi, Prestasi Belajar, Unit Kegiatan Mahasiswa 
Pendidikan adalah suatu fasilitas untuk menciptakan sumber daya manusia yang berkualitas tinggi. Pendidikan dapat diharapkan untuk meningkatkan kemampuan, martabat bangsa Indonesia, mutu,dan kehidupan. Oleh karena itu pendidikan nasional dapat diharapkan untuk menghasilkan sumber daya manusia berpendidik yang beriman, berketrampilan, berpengetahuan, berbudi pekerti luhur, dan memiliki rasa tanggung jawab.

Perguruan tinggi adalah salah satu lembaga pendidikan yang memiliki tujuan untuk mewujudkan dan merealisaikan tujuan pendidikan nasional. Kegiatan kemahasiswaan yang diberikan oleh perguruan tinggi diharapkan dapat menunjang dalam meningkatkan kualitas kemampuan sikap dan intelektual mahasiswa. Kegiatan kemahasiswaan juga diharapkan mampu menjadi fasilitas untuk mahasiswa dalam mengembangkan prestasi dalam bidang akademik maupun non akademik.

Berbagai cara dapat dilakukan dalam membantu mengembangkan potensi kemahasiswaan secara maksimal dengan salah satunya melalui dalam kegiatan pengembangan bakat, minat, pemikiran yang kritis, produktif, kreatif, dan inovatif. Dalam perguruan tinggi setiap mahasiswa diberikan kesempatan untuk mengikuti kegiatan diluar kegiatan akademik misalnya kegiatan kemahasiwaan dan unit-unit kegiatan mahasiswa yang ada didalam perguruan tinggi tersebut.

Berbagai macam organisasi kemahasiswa yang ada didalam perguruan tinggi atau universitas banyak dijumpai dikarenakan organisasi memang sangat penting bagi mahasiswa untuk mengembangkan kepribadian, ketrampilan, dan intelektual mahasiswa, mulai dari organisasi tingkat jurusan atau program studi, fakultas, dan universitas. Aktivitas dalam berorganisasi adalah salah satu dari kegiatan yang dilakukan mahasiswa diluar jam belajar dalam rangka mengembangkan minat dan bakat setiap mahasiswa.

Organisasi memiliki tujuan sebagai wadah dalam mengembangkan dan mengasah kemampuan yang dimiliki setiap mahasiswa. Dan tidak dapat dipungkiri setiap kegiatan yang berhubungan dengan mahasiswa pasti akan ada dampak yang positif dan negatif dari keikutsertaan mahasiswa dalam organisasi kemahasiswaan. Terdapat tiga pengaruh positif dari keikutsertaan mahasiswa kedalam organisasi adalah mahasiswa dapat mengembangkan kemandiriannya, mengaktualisasikan dirinya, dan mempunyai cara berpikir yang dapat mencari solusi jika terdapat masalah jika berada di tengah masyarakat. Dan terdapat pengaruh negatif yang mungkin nantinya timbul salah satunya adalah mahasiswa lambat dalam menyelesaikan perkuliahanya, bahkan aka nada mahasiswa yang memiliki idealis tinggi dalam organisasinya dapat menjadi rawan drop out (DO). Pandangan seperti ini perlu dirubah dan dikaji lebih dalam lagi dikarenakan tidak semua mahasiswa yang aktif dalam berorganisasi tidak dapat meraih prestasi belajar dengan predikat dengan pujian.

Didalam mengikuti organisasi setiap mahasiswa dituntut untuk selalu mencari pengalaman serta ilmu yang bermanfaat dengan jalan mengikuti kegiatan didalam organisasi itu sehingga dapat menunjang prestasi mahasiswa baik akademik dan non akademik. Banyak orang memiliki pendapat bahwa organisasi akan memperhambat perkuliahan. Berbagai persepsi, pandangan serta paradigma untuk mahasiswa yang aktif dalam berorganisasi kemahasiswaan, antara lain: (1) buang-buang waktu, (2) menurunnya nilai mahasiwa karena terlalu sibuk di organisasi, sedangkan kuliah sering terabaikan, (3) organisasi itu tidak penting, (4) tidak ada manfaatnya dalam berorganisasi, hanya akan menghambat kegiatan perkuliah. Akan tetapi semua itu dikembalikan kepada setiap individu mahasiswa yang mengikuti organisasi kemahasiswa, yaitu dengan mengatur waktu antara organisasi dan perkuliahan dengan baik dan optimal.

Berdasarkan hasil observasi yang dilakukan kepada beberapa mahasiswa yang menjadi pengurus harian dan anggota UKM, ada beberapa permasalahan yang harus dihadapi oleh mahasiswa dalam berorganisasi, beberapa diantaranya seringnya mahasiswa tertidur didalam kelas, kesulitan dalam membadi waktu antara kuliah dan berorganisasi, kurang kedisiplinan dalam perkuliahan, turunnya nilai akademik mahasiswa, seringnya terjadi prioritas utama adalah berorganisasi bukan perkuliahan, masa study yang lama, kurang seimbangnya keaktifan antara perkuliahan dan berorganisasi. Mahasiswa harus dapat mengatur antara keduanya dengan maksimal. Bagi sebagian aktifis, kegiatan berorganisasi merupakan kegiatan yang berharga karena sebuah pengalaman yang tidak dapat diperoleh kedua kalinya 
dikemudian hari setelah lulus dari universitas. Sementara itu mahasiswa memiliki tanggung jawab dimana harus mendapat nilai yang dalam prestasi akademik dengan maksismal.

Prestasi belajar yang memuaskan dapat diperoleh mahasiswa apabila mahasiswa tidak mudah menyerah dan pandai dalam mengatur waktu. Setiap mahasiswa dalam mencapai keberhasilan dalam menyelesaikan studi sesuai dengan waktu yang telah dan berprestasi yang memuaskan tanpa adanya pengesampingan kegiatan berorganisasi merupakan salah satu kebanggan tersendiri 5 karena Indeks Prestasi Kumulatif (IPK) merupakan indikator utama dalam menentukan prestasi belajar mahasiswa (Basori, 2016).

Motivasi belajar merupakan suatu daya pendorong bagi mahasiswa untuk melakukan kegiatan belajar karena dalam motivasi belajar terdapat semangat dan adanya keinginan mahasiswa yang besar untuk mengikuti pembelajaran yang lebih baik (Dimyati dan Mudjiono, 2002: 85). Selain itu, motivasi belajar dapat dilihat dari 2 faktor, yaitu faktor internal dan faktor eksternal. Menurut Syah (2004:132), faktor internal (faktor dari dalam diri individu), meliputi keadaan atau kondisi jasmani dan rohani mahasiswa dan faktor eksternal (faktor dari luar diri individu), meliputi kondisi lingkungan sekitar mahasiswa.

Ada tiga kebutuhan atau keinginan manusia yang menonjol menurut McClelland (dalam Winardi, 2011). Pertama, kebutuhan berprestasi (dorongan untuk mengungguli, berprestasi sehubungan dengan seperangkat standar prestasi, bergulat untuk sukses). Kedua, kebutuhan akan afiliasi (hasrat untuk hubungan antarpribadi yang ramah dan karib). Ketiga, kebutuhan akan kekuasaan. McClelland mendefinisikan bahwa motivasi sebagai dorongan untuk mencapai keberhasilan dalam berkompetisis dengan seperangkat standar prestasi (success in competition with some standard of excellence). Selanjutnya McClelland (dalam Winardi, 2011) menjelaskan salah satu faktor yang dapat memunculkan timbulnya motivasi pada diri setiap orang ialah adanya kebutuhan berprestasi. Kebutuhan meliputi beberapa keinginan dalam mengatasi rintangan, menyelesaikan sesuatu yang sulit dan keinginan untuk dapat melebihi orang lain, mencapai setiap kesuksesan.

Dari pengertian tentang motivasi dapat disimpulkan bahwa setiap mahasiswa memiliki motivasi untuk mencapai tujuan berprestasi di setiap bidangnya yang sudah di rencanakan mulai awal. Prestasi belajar di dapat dari belajar seperti yang dikatakan Gunarso (dalam Sunarto, 2012: 1) bahwa prestasi belajar adalah hasil dari usaha setiap individu setelaha melaksanakan usaha-usaha dalam belajar. Prestasi dapat diukur melalui tes bias juga disebut dengan tes prestasi belajar. Untuk mencapai prestasi yang memuaskan diperlukan keaktifan mahasiswa yang dimana akan menjadi indikator untuk mencapai prestasi belajar yang memuaskan, khususnya mahasiswa yang mengikuti Unit Kegiatan Mahasiswa yang selanjutnya disebut UKM.

UKM ialah "lembaga yang sederajat dengan organisasi kemahasiswaan diintra kampus seperti badan eksekutif mahasiswa dan senat mahasiswa, baik berasal dari tingkat progam studi, jurusan, maupun universitas", menurut Hermit (2007). Lembaga ini bersifat otonom dan bukan juga dari cabang dari badan esekutif maupun senat mahasiswa. Univesitas Negeri Malang (UM) memiliki 31 UKM yang terdiri dari berbagai kelompok bidang minat, seperti bidang minta olah raga, bidang minat kesenian, bidang minat bela diri, bidang minat penalaran, bidang minat kerohanian dan bing minat khusus.

Prestasi dapat diperoleh setiap mahasiswa, baik yang menjadi pengurus harian atau anggota UKM bukan alasan untuk menjadikan prestasi menurun, dibalik itu harus ada motivasi belajar yang mendukung untuk mendapatkan prestasi yang tinggi.

Berdasarkan latar belakang tersebut maka peneliti menduga bahwa akan terdapat perbedaan motivasi belajar antara mahasiswa yang menjadi pengurus harian dan anggota UKM dan prestasi belajar antara mahasiswa yang menjadi pengurus harian dan anggota UKM. Rencana penelitian ini akan dilakukan pada mahasiswa Universitas Negeri Malang yang menjadi pengurus harian dan anggota UKM dengan jumlah semua 112 mahasiswa yang pengurus harian dan 907 anggota UKM angkatan 2015 dan 2016. Berdasarkan hal tersebut maka peneliti tertarik untuk mengadakan penelitian skripsi dengan judul penelitian "Perbedaan Motivasi dan Prestasi Belajar Antara Pengurus Harian dan Anggota Unit Kegiatan Mahasiswa (UKM) Universitas Negeri Malang". 


\section{METODE}

Penelitian ini mennggunakan pendekatan kuantitatif. Penelitian ini juga menggunakan penelitian deskriptif-kausal komparatif, Penelitian deskriptif merupakan jenis penelitian yang mengarah pada penggambaran gejala-gejala, fakta-fakta, atau kejadian-kejadian yang akurat dansistematis, tentang sifat-sifat populasi atau suatu daerah tertentu (Zuriah, 2008:47). Dalam penelitian ini, rancangan deskriptif digunakan peneliti untuk mengungkapkan motivasi belajar dan prestasi belajar pengurus harian dan anggota UKM UM.Penelitian kausal komparatif memiliki tujuan untuk membandingkan satu variable atau lebih dengan sampel besar, atau penelitian dilakukan dengan mengkaji beberapa fenomena-fenomena sosial dalam bidang pendidikan, kemudian dicoba pada lembaga pendidikan yang lain (Iskandar, 2009:62). Tujuan penelitian kausal komparatif adalah untuk menemukan perbedaan atau kesamaan teori. Penilitian ini bertujuan untuk mengatuhi ada atau tidaknya perbedaan motivasi belajar dan prestasi belajar pengurus harian dan anggota UKM UM. Analisis data kuantitatif atau statistik yang memiliki tujuan untuk menguji hipotesis yang telah ditetapkan. Adapun kerangka pemikiran yang dibuat oleh peneliti dapat dilihat pada Gambar 1 .

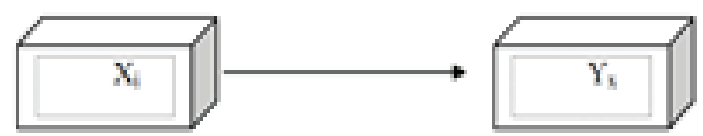

Gambar 1 Rancangan Penelitian

Keterangan:

$\mathrm{X}_{\mathrm{i}}=$ Jumlah variabel $\mathrm{X}$ motivasi dan prestasi belajar.

$\mathrm{Y}_{\mathrm{x}}=$ Jumlah variabel $\mathrm{Y}$ pengurus harian dan anggota UKM.

Penelitian ini menggunakan sampel sejumlah 22 pengurus harian dan 181 anggota UKM dari populasi 112 pengurus harian dan 907 anggota UKM dengan lokasi penilitian di Unit Kegiatan Mahasiswa (UKM) Universitas Negeri Malang. Instrumen yang digunakan oleh peneliti berupa angket. Teknik analisis data yang digunakan yaitu analisis deskriptif dan uji Test dengan menggunakan program SPSS (Statistical Product and Service Solution) for Windows versi 24.0.

\section{HASIL}

\section{Analisis Deskriptif}

\section{Variabel Motivasi Belajar}

\section{Pengurus Harian UKM}

Hasil analisis deskriptif variabel motivasi belajar yang menjadi pengurus harian UKM dirangkum dalam Tabel 1 berikut :

Tabel 1 Kelas Interval Pengurus Harian

\begin{tabular}{lccccc}
\hline No & Interval Rendah & Interval Tinggi & Frekuensi & Persentase & Kategori \\
\hline 1 & 44 & 77 & 0 & $0.0 \%$ & Sangat Rendah \\
2 & 77,001 & 110,001 & 1 & $4.5 \%$ & Rendah \\
3 & 110,002 & 143,002 & 13 & $59.1 \%$ & Tinggi \\
4 & 143,001 & 176,001 & 8 & $36.4 \%$ & Sangat Tinggi \\
Jumlah & & & 22 & $100 \%$ & \\
Rata-Rata & & & & 136.36 \\
Kategori & & & & & Tinggi \\
\hline
\end{tabular}


Pada Tabel 1 di atas dapat diketahui bahwa rata-rata motivasi belajar yang menjadi pengurus harian UKM sebesar 136.36. Hal ini menunjukkan motivasi belajar yang menjadi pengurus harian UKM berada pada kategori tinggi. Frekuensi paling banyak berada pada interval 110 - 143 sebanyak 13 (59.1\%) mahasiswa. Mahasiswa yang memiliki motivasi belajar sangat tinggi berada pada interval $143-176$ sebanyak 8 (36.4\%) mahasiswa. Mahasiswa yang memiliki motivasi belajar tinggi berada pada interval 110 - 143 sebanyak 13 (59.1\%) mahasiswa. Mahasiswa yang memiliki motivasi belajar sedang berada pada interval 77 - 110 sebanyak 1 (4.5\%) mahasiswa dan mahasiswa yang memiliki motivasi belajar rendah berada pada interval 44 - 77 sebanyak $0(0.0 \%)$ mahasiswa.

\section{Anggota UKM}

Hasil analisis deskriptif variabel motivasi belajar yang menjadi anggota UKM dirangkum dalam Tabel 2 berikut :

Tabel 2 Kelas Interval Anggota UKM

\begin{tabular}{lccccc}
\hline No & Interval Rendah & Interval Tinggi & Frekuensi & Persentase & Kategori \\
\hline 1 & 44 & 77 & 0 & $0.0 \%$ & Sangat Rendah \\
2 & 77,001 & 110,001 & 6 & $3.3 \%$ & Rendah \\
3 & 110,002 & 143,002 & 102 & $56.4 \%$ & Tinggi \\
4 & 143,001 & 176,001 & 73 & $40.3 \%$ & Sangat Tinggi \\
Jumlah & & 181 & $100 \%$ & \\
Rata - rata & & & & 139.85 \\
Kategori & & & & Tinggi \\
\hline
\end{tabular}

Pada Tabel 2 di atas dapat diketahui bahwa rata-rata motivasi belajar yang menjadi anggota UKM sebesar 139.85. Hal ini menunjukkan motivasi belajar yang menjadi anggota UKM berada pada kategori tinggi. Frekuensi paling banyak berada pada interval 110 - 143 sebanyak 102 (56.4\%) mahasiswa. Mahasiswa yang memiliki motivasi belajar sangat tinggi berada pada interval 143 - 176 sebanyak 73 (40.3\%) mahasiswa. Mahasiswa yang memiliki motivasi belajar tinggi berada pada interval 110 - 143 sebanyak 102 (56.4\%) mahasiswa. Mahasiswa yang memiliki motivasi belajar sedang berada pada interval 77 - 110 sebanyak 6 (3.3\%) mahasiswa dan mahasiswa yang memiliki motivasi belajar rendah berada pada interval 44 - 77 sebanyak $0(0.0 \%)$ mahasiswa.

\section{Variabel Prestasi Akademik}

\section{Pengurus Harian UKM}

Deskripsi rata-rata prestasi akademik pengurus harian dapat dilihat pada Tabel 4.3.

Tabel 4.3 Rata-rata Prestasi Akademik Pengurus Harian

\begin{tabular}{|c|c|c|c|c|c|c|c|}
\hline \multirow{3}{*}{ Predikat } & \multicolumn{5}{|c|}{ Angkatan } & \multirow{3}{*}{ Jumlah } & \multirow{3}{*}{ Rata - rata } \\
\hline & \multicolumn{3}{|c|}{2015} & \multicolumn{2}{|c|}{2016} & & \\
\hline & $\begin{array}{c}\text { Semester } \\
4\end{array}$ & $\begin{array}{c}\text { Semester } \\
5\end{array}$ & $\begin{array}{c}\text { Semester } \\
6\end{array}$ & $\begin{array}{c}\text { Semester } \\
4\end{array}$ & $\begin{array}{c}\text { Semester } \\
5\end{array}$ & & \\
\hline Dengan Pujian & 4 & 3 & 4 & 3 & 3 & 17 & 3.4 \\
\hline Sangat Memuaskan & 4 & 4 & 4 & 10 & 11 & 33 & 6.6 \\
\hline Memuaskan & $\mathbf{0}$ & 1 & $\mathbf{0}$ & 1 & $\mathbf{0}$ & 2 & 0.4 \\
\hline
\end{tabular}

Pada Tabel 3 diatas dapat diketahui bahwa rata-rata prestasi akademik pengurus harian tertinggi pada kategori sangat memuaskan. 


\section{Anggota UKM}

Deskripsi rata-rata prestasi akademik Anggota UKM dapat dilihat pada Tabel 4.

Tabel 4 Rata-rata Prestasi Akademik Anggota UKM

\begin{tabular}{|l|c|c|c|c|c|c|c|}
\hline \multirow{3}{*}{ Predikat } & \multicolumn{5}{|c|}{ Angkatan } & \multirow{3}{*}{ Jumlah } & \multirow{2}{*}{ Rata -rata } \\
\cline { 2 - 8 } & \multicolumn{4}{|c|}{2015} & \multicolumn{2}{c|}{2016} \\
\cline { 2 - 8 } & Semester & Semester & Semester & Semester & Semester & & \\
\hline Dengan Pujian & 4 & 5 & 6 & 4 & 5 & & 47.8 \\
\hline Sangat Memuaskan & 33 & 21 & 14 & 61 & 48 & 177 & 35.4 \\
\hline Memuaskan & 0 & 1 & 0 & 0 & 4 & 5 & 1 \\
\hline
\end{tabular}

Pada Tabel 4 diatas dapat diketahui bahwa rata-rata prestasi akademik pengurus harian tertinggi pada kategori dengan pujian.

\section{Variabel Prestasi Non Akademik}

\section{Data Prestasi Non Akademik Pengurus Harian}

Deskripsi data prestasi non akademik pengurus hariann dapat dilihat pada Tabel 5.

Tabel 5 Prestasi Non Akademik Pengurus Harian

\begin{tabular}{lcc}
\hline Tingkat & Frekuensi & Presentase \\
\hline Malang Raya & 14 & $33 \%$ \\
Jawa Timur & 10 & $24 \%$ \\
Nasional & 18 & $43 \%$ \\
Jumlah & 42 & $100 \%$ \\
\hline
\end{tabular}

Berdasarkan Tabel 5 di atas, dapat diketahui bahwa sebagian besar mahasiswa pengurus harian UKM memperoleh prestasi non akademik tingkat Nasional sebesar 43\%. Selanjutnya sebesar 33\% mahasiswa pengurus harian UKM memperoleh prestasi non akademik tingkat Malang Raya dan sisanya sebesar 24\% mahasiswa pengurus harian UKM memperoleh prestasi non akademik tingkat Jawa Timur.

\section{Data Prestasi Non Akademik Anggota UKM}

Deskripsi data prestasi non akademik anggota UKM dapat dilihat pada Tabel 6.

Tabel 6 Prestasi Non Akademik Anggota UKM

\begin{tabular}{lcc}
\hline Tingkat & Frekuensi & Presentase \\
\hline Malang Raya & 37 & $23 \%$ \\
Jawa Timur & 56 & $35 \%$ \\
Nasional & 69 & $43 \%$ \\
\hline Jumlah & 162 & $100 \%$ \\
\hline
\end{tabular}

Berdasarkan Tabel 6 di atas, dapat diketahui bahwa sebagian besar mahasiswa anggota UKM memperoleh prestasi non akademik tingkat Nasional sebesar 43\%. Selanjutnya sebesar $35 \%$ mahasiswa anggota UKM memperoleh prestasi non akademik tingkat Jawa Timur dan sisanya sebesar $23 \%$ mahasiswa anggota UKM memperoleh prestasi non akademik tingkat Malang Raya. 


\section{UJI HIPOTESIS}

\section{Analisis Perbedaan Motivasi Belajar Mahasiswa yang Menjadi Pengurus Harian UKM dan yang Menjadi Anggota UKM}

\section{Pengujian Kenormalan Data}

Pengujian kenormalan data motivasi belajar mahasiswa yang menjadi pengurus harian UKM dan yang menjadi anggota UKM bertujuan untuk mengetahui normal tidaknya data motivasi belajar mahasiswa yang menjadi pengurus harian UKM dan yang menjadi anggota UKM. Pengujian kenormalan data motivasi belajar mahasiswa yang menjadi pengurus harian UKM dan yang menjadi anggota UKM dilakukan menggunakan Kolmogorov-Smirnov, dengan kriteria apabila nilai probabilitas $>$ level of significance $($ alpha $=5 \%$ ) maka data motivasi belajar mahasiswa yang menjadi pengurus harian UKM dan yang menjadi anggota UKM dinyatakan normal. Hasil pengujian normalitas data motivasi belajar mahasiswa yang menjadi pengurus harian UKM dan yang menjadi anggota UKM dapat dilihat melalui tabel berikut :

Tabel 7 Uji Kenormalan Motivasi Belajar

\begin{tabular}{lll}
\hline Kelompok & Kolmogorov Smirnov & Probabilitas \\
\hline Pengurus Harian UKM & $\mathbf{0 . 1 0 4}$ & $\mathbf{0 . 2 0 0}$ \\
Anggota UKM & $\mathbf{0 . 0 6 3}$ & $\mathbf{0 . 0 8 1}$ \\
\hline
\end{tabular}

Berdasarkan Tabel 7 di atas dapat diketahui bahwa pengujian normalitas pada data motivasi belajar mahasiswa yang menjadi pengurus harian UKM dan yang menjadi anggota UKM secara berturut-turut menghasilkan statistik Kolmogorov-Smirnov sebesar 0.104 dan 0.063 dengan probabilitas sebesar 0.200 dan 0.081. Hal ini dapat diketahui bahwa pengujian data motivasi belajar mahasiswa yang menjadi pengurus harian UKM menghasilkan probabilitas $>$ alpha (5\%), sehingga data motivasi belajar mahasiswa yang menjadi anggota UKM dinyatakan normal sedangkan motivasi belajar mahasiswa yang menjadi anggota UKM menghasilkan probabilitas > alpha (5\%), sehingga data motivasi belajar mahasiswa yang menjadi anggota UKM dinyatakan normal.

\section{Pengujian Homogenitas Data}

Pengujian homogenitas data motivasi belajar mahasiswa yang menjadi pengurus harian UKM dan yang menjadi anggota UKM bertujuan untuk mengetahui apakah data memiliki ragam yang homogen atau tidak. Pengujian kehomogenan data motivasi belajar mahasiswa yang menjadi pengurus harian UKM dan yang menjadi anggota UKM dilakukan menggunakan Levene Test, dengan kriteria apabila nilai probabilitas >level of significance $($ alpha $=5 \%$ ) maka data dinyatakan homogen. Hasil pengujian homogenitas data motivasi belajar mahasiswa yang menjadi pengurus harian UKM dan yang menjadi anggota UKM dapat dilihat melalui tabel berikut:

Tabel 8 Uji Homogennitas Motivasi Belajar

\begin{tabular}{ll}
\hline Levene Statistic & 0.258 \\
\hline Probabilitas & 0.612 \\
\hline
\end{tabular}

Berdasarkan data Tabel 8 di atas dapat diketahui bahwa pengujian kehomogenan data motivasi belajar mahasiswa yang menjadi pengurus harian UKM dan yang menjadi anggota UKM menghasilkan statistik Levene sebesar 0.258 dengan probabilitas sebesar 0.612. Hal ini dapat diketahui bahwa pengujian data motivasi belajar mahasiswa yang menjadi pengurus harian UKM dan yang menjadi anggota UKM menghasilkan probabilitas > alpha (5\%), sehingga data tersebut dinyatakan memiliki ragam yang homogen.

\section{Pengujian Hipotesis 1}

Pengujian perbedaan motivasi belajar mahasiswa yang menjadi pengurus harian UKM dan yang menjadi anggota UKM dilakukan menggunakan Indenpendent $T$ Test dengan hipotesis berikut ini:

H0 : Tidak terdapat perbedaan yang signifikan motivasi belajar mahasiswa yang menjadi pengurus harian UKM dan yang menjadi anggota UKM. 
Kriteria pengujian menyebutkan apabila probabilitas $<$ level of significance $($ alpha $=5 \%$ ) makaa H0 ditolak, sehingga dapat dinyatakan bahwa terdapat perbedaan yang signifikan motivasi belajar mahasiswa yang menjadi pengurus harian UKM dan yang menjadi anggota UKM. Hasil pengujian perbedaan motivasi belajar mahasiswa yang menjadi pengurus harian UKM dan yang menjadi anggota UKM dapat diketahui melalui tabel berikut :

Tabel 9 Uji T Motivasi Belajar

\begin{tabular}{llll}
\hline Kelompok & Rata-Rata & Independent T Test & Probabilitas \\
\hline Pengurus Harian UKM & 136.364 & 0.940 & 0.349 \\
Anggota UKM & 139.851 & & \\
\hline
\end{tabular}

Berdasarkan hasil pengujian yang tertera pada Tabel 9 di atas dapat diketahui bahwa statistik uji $T$ yang dihasilkan sebesar 0.940 dan probabilitas 0.349 . Hal ini berarti probabilitas $>$ alpha (5\%). Dengan demikian dapat dinyatakan bahwa terdapat perbedaan yang signifikan motivasi belajar mahasiswa yang menjadi pengurus harian UKM dan yang menjadi anggota UKM. Ditinjau dari rata-rata motivasi belajar mahasiswa yang menjadi anggota UKM bernilai lebih tinggi dari rata-rata motivasi belajar mahasiswa yang menjadi pengurus harian UKM.

\section{Analisis Perbedaan Prestasi Belajar Akademik Mahasiswa yang Menjadi Pengurus Harian UKM dan yang Menjadi Anggota UKM}

\section{Pengujian Kenormalan Data}

Pengujian kenormalan data prestasi belajar akademik mahasiswa yang menjadi pengurus harian UKM dan yang menjadi anggota UKM bertujuan untuk mengetahui normal tidaknya data prestasi belajar akademik mahasiswa yang menjadi pengurus harian UKM dan yang menjadi anggota UKM. Pengujian kenormalan data prestasi belajar akademik mahasiswa yang menjadi pengurus harian UKM dan yang menjadi anggota UKM dilakukan menggunakan Kolmogorov-Smirnov, dengan kriteria apabila nilai probabilitas $>$ level of significance $($ alpha $=5 \%$ ) maka data prestasi belajar akademik mahasiswa yang menjadi pengurus harian UKM dan yang menjadi anggota UKM dinyatakan normal. Hasil pengujian normalitas data prestasi belajar akademik mahasiswa yang menjadi pengurus harian UKM dan yang menjadi anggota UKM dapat dilihat melalui tabel berikut :

Tabel 10 Uji Kenormalan Data Prestasi Belajar Akademik

\begin{tabular}{lll}
\hline Kelompok & Kolmogorov Smirnov & Probabilitas \\
\hline Pengurus Harian UKM & 0.130 & 0.200 \\
Anggota UKM & 0.064 & 0.065 \\
\hline
\end{tabular}

Dapat dilihat diTabel 10 di atas dapat diketahui bahwa pengujian normalitas pada data prestasi belajar akademik mahasiswa yang menjadi pengurus harian UKM dan yang menjadi anggota UKM secara berturut-turut menghasilkan statistik Kolmogorov-Smirnov sebesar 0.130 dan 0.064 dengan probabilitas sebesar 0.200 dan 0.065 . Hal ini dapat diketahui bahwa pengujian data prestasi belajar akademik mahasiswa yang menjadi pengurus harian UKM menghasilkan probabilitas $>$ alpha $(5 \%)$, sehingga data prestasi belajar akademik mahasiswa yang menjadi anggota UKM dinyatakan normal sedangkan prestasi belajar akademik mahasiswa yang menjadi anggota UKM menghasilkan probabilitas $>$ alpha $(5 \%)$, sehingga data prestasi belajar akademik mahasiswa yang menjadi anggota UKM dinyatakan normal.

\section{Pengujian Homogenitas Data}

Pengujian homogenitas data prestasi belajar akademik mahasiswa yang menjadi pengurus harian UKM dan yang menjadi anggota UKM bertujuan untuk mengetahui apakah data memiliki ragam yang homogen atau tidak. Pengujian kehomogenan data prestasi belajar akademik mahasiswa yang menjadi pengurus harian UKM dan yang menjadi anggota UKM dilakukan menggunakan Levene Test, dengan kriteria apabila nilai probabilitas >level of significance $($ alpha $=5 \%)$ maka data dinyatakan homogen. 
Hasil pengujian homogenitas data prestasi belajar akademik mahasiswa yang menjadi pengurus harian UKM dan yang menjadi anggota UKM dapat dilihat melalui tabel berikut :

Tabel 11 Uji Homogenitas Prestasi Belajar Akademik

\begin{tabular}{l|l}
\hline Levene Statistic & 12.655 \\
\hline Probabilitas & 0.000 \\
\hline
\end{tabular}

Berdasarkan data Tabel 11 di atas dapat diketahui bahwa pengujian kehomogenan data prestasi belajar akademik mahasiswa yang menjadi pengurus harian UKM dan yang menjadi anggota UKM menghasilkan statistik Levene sebesar 12.655 dengan probabilitas sebesar 0.000. Hal ini dapat diketahui bahwa pengujian data prestasi belajar akademik mahasiswa yang menjadi pengurus harian UKM dan yang menjadi anggota UKM menghasilkan probabilitas < alpha (5\%), sehingga data tersebut dinyatakan tidak memiliki ragam yang homogen.

\section{Pengujian Hipotesis 2.1}

Pengujian perbedaan prestasi belajar akademik mahasiswa yang menjadi pengurus harian UKM dan yang menjadi anggota UKM dilakukan menggunakan Indenpendent T Test dengan hipotesis berikut ini: H0 : Tidak terdapat perbedaan yang signifikan prestasi belajar akademik mahasiswa yang menjadi pengurus harian UKM dan yang menjadi anggota UKM

Kriteria pengujian menyebutkan apabila probabilitas $<$ level of significance $($ alpha $=5 \%)$ makaa H0 diterima, sehingga dapat dinyatakan bahwa terdapat perbedaan yang signifikan prestasi belajar akademik mahasiswa yang menjadi pengurus harian UKM dan yang menjadi anggota UKM.

Hasil pengujian perbedaan prestasi belajar akademik mahasiswa yang menjadi pengurus harian UKM dan yang menjadi anggota UKM dapat diketahui melalui tabel berikut :

Tabel 12 Uji T Prestasi Belajar Akademik

\begin{tabular}{|c|c|c|c|}
\hline Kelompok & Rata-Rata & Independent T Test & Probabilitas \\
\hline Pengurus Harian UKM & 3.394 & \multirow{2}{*}{2.422} & \multirow{2}{*}{0.024} \\
\hline Anggota UKM & 3.525 & & \\
\hline
\end{tabular}

Berdasarkan hasil pengujian yang tertera pada Tabel 12 di atas dapat diketahui bahwa statistik uji $T$ yang dihasilkan sebesar 2.422 dan probabilitas 0.024 . Hal ini berarti probabilitas < alpha (5\%). Dengan demikian dapat dinyatakan bahwa terdapat perbedaan yang signifikan prestasi belajar akademik mahasiswa yang menjadi pengurus harian UKM dan yang menjadi anggota UKM. Ditinjau dari ratarata prestasi belajar akademik mahasiswa yang menjadi anggota UKM bernilai lebih tinggi dari rata-rata prestasi belajar akademik mahasiswa yang menjadi pengurus harian UKM.

\section{Analisis Perbedaan Prestasi Belajar Non akademik Mahasiswa yang Menjadi Pengurus Harian UKM dan yang Menjadi Anggota UKM}

\section{Pengujian Kenormalan Data}

Pengujian kenormalan data prestasi belajar non akademik mahasiswa yang menjadi pengurus harian UKM dan yang menjadi anggota UKM bertujuan untuk mengetahui normal tidaknya data prestasi belajar non akademik mahasiswa yang menjadi pengurus harian UKM dan yang menjadi anggota UKM. Pengujian kenormalan data prestasi belajar non akademik mahasiswa yang menjadi pengurus harian UKM dan yang menjadi anggota UKM dilakukan menggunakan Kolmogorov-Smirnov, dengan kriteria apabila nilai probabilitas $>$ level of significance $($ alpha $=5 \%)$ maka data prestasi belajar non akademik mahasiswa yang menjadi pengurus harian UKM dan yang menjadi anggota UKM dinyatakan normal. Hasil pengujian normalitas data prestasi belajar non akademik mahasiswa yang menjadi pengurus harian UKM dan yang menjadi anggota UKM dapat dilihat melalui tabel berikut : 
Tabel 13 Uji Kenormalan Prestasi Belajar Non Akademik

\begin{tabular}{lll}
\hline Kelompok & Kolmogorov Smirnov & Probabilitas \\
\hline Pengurus Harian UKM & 0.291 & 0.000 \\
Anggota UKM & 0.403 & 0.000 \\
\hline
\end{tabular}

Berdasarkan data di atas dapat diketahui bahwa pengujian normalitas pada data prestasi belajar non akademik mahasiswa yang menjadi pengurus harian UKM dan yang menjadi anggota UKM secara berturut-turut menghasilkan statistik Kolmogorov-Smirnov sebesar 0.291 dan 0.403 dengan probabilitas sebesar 0.000 dan 0.000 . Hal ini dapat diketahui bahwa pengujian data prestasi belajar non akademik mahasiswa yang menjadi pengurus harian UKM menghasilkan probabilitas $<$ alpha (5\%), sehingga data prestasi belajar non akademik mahasiswa yang menjadi anggota UKM dinyatakan tidak normal sedangkan prestasi belajar non akademik mahasiswa yang menjadi anggota UKM menghasilkan probabilitas $<$ alpha $(5 \%)$, sehingga data prestasi belajar non akademik mahasiswa yang menjadi anggota UKM dinyatakan tidak normal.

\section{Pengujian Homogenitas Data}

Pengujian homogenitas data prestasi belajar non akademik mahasiswa yang menjadi pengurus harian UKM dan yang menjadi anggota UKM bertujuan untuk mengetahui apakah data memiliki ragam yang homogen atau tidak. Pengujian kehomogenan data prestasi belajar non akademik mahasiswa yang menjadi pengurus harian UKM dan yang menjadi anggota UKM dilakukan menggunakan Levene Test, dengan kriteria apabila nilai probabilitas >level of significance (alpha $=5 \%$ ) maka data dinyatakan homogen. Hasil pengujian homogenitas data prestasi belajar non akademik mahasiswa yang menjadi pengurus harian UKM dan yang menjadi anggota UKM dapat dilihat melalui tabel berikut :

Tabel 14 Uji Homogenitas Prestasi Belajar Non Akademik

\begin{tabular}{ll}
\hline Levene Statistic & 0.489 \\
Probabilitas & 0.485 \\
\hline
\end{tabular}

Berdasarkan data Tabel 14 di atas dapat diketahui bahwa pengujian kehomogenan data prestasi belajar non akademik mahasiswa yang menjadi pengurus harian UKM dan yang menjadi anggota UKM menghasilkan statistik Levene sebesar 0.489 dengan probabilitas sebesar 0.485 . Hal ini dapat diketahui bahwa pengujian data prestasi belajar non akademik mahasiswa yang menjadi pengurus harian UKM dan yang menjadi anggota UKM menghasilkan probabilitas $>$ alpha (5\%), sehingga data tersebut dinyatakan memiliki ragam yang homogen.

\section{Pengujian Hipotesis 2.2}

Pengujian perbedaan prestasi belajar non akademik mahasiswa yang menjadi pengurus harian UKM dan yang menjadi anggota UKM dilakukan menggunakan Mann Whitney Test dengan hipotesis berikut ini. H0 : Tidak terdapat perbedaan yang signifikan prestasi belajar non akademik mahasiswa yang menjadi pengurus harian UKM dan yang menjadi anggota UKM.

Kriteria pengujian menyebutkan apabila probabilitas $<$ level of significance (alpha $=5 \%$ ) makaa H0 ditolak, sehingga dapat dinyatakan bahwa terdapat perbedaan yang signifikan prestasi belajar non akademik mahasiswa yang menjadi pengurus harian UKM dan yang menjadi anggota UKM. Hasil pengujian perbedaan prestasi belajar non akademik mahasiswa yang menjadi pengurus harian UKM dan yang menjadi anggota UKM dapat diketahui melalui tabel berikut :

Tabel 15 Uji Z Prestasi Belajar Non Akademik

\begin{tabular}{llll}
\hline Kelompok & Rata-Rata & Mann Whitney Test & Probabilitas \\
\hline Pengurus Harian UKM & 1.909 & & \\
Anggota UKM & 0.895 & -5.139 & 0.000 \\
\hline
\end{tabular}


Berdasarkan hasil pengujian yang tertera pada Tabel 15 di atas dapat diketahui bahwa statistik uji Z yang dihasilkan sebesar -5.139 dan probabilitas 0.000 . Hal ini berarti probabilitas $<$ alpha (5\%). Dengan demikian dapat dinyatakan bahwa terdapat perbedaan yang signifikan prestasi belajar non akademik mahasiswa yang menjadi pengurus harian UKM dan yang menjadi anggota UKM. Ditinjau dari rata-rata prestasi belajar non akademik mahasiswa yang menjadi pengurus harian UKM bernilai lebih tinggi dari rata-rata prestasi belajar non akademik mahasiswa yang menjadi anggota UKM.

\section{PEMBAHASAN}

\section{Motivasi Belajar Mahasiswa}

Ada dua jenis motivasi belajar, yaitu motivasi intrinsic dan ekstrinsik (Sardiman, 2001:87). Motivasi intriksik merupakan pendorong kerja dari dalam pekerja sebagai individu (Nawawi, 2001:359) sedangkan motivasi ekstrinsik merupakan pendorong kerja yang bersumber dari luar diri pekerja sebagai individu (Nawawi, 2001:359). Dimyati dan Mudjiono (2010:97) memaparkan beberapa faktor yang menjadi penyebab seseorang termotivasi yaitu, adanya cita-cita dan aspirasi siswa untuk mewujudkan aktualisasi diri, kemampuan siswa yang mendukung, kondisi diri siswa (rohani dan jasmani), kondisi lingkungan siswa (alam dan sosial) serta unsur-unsur dinamis dalam belajar dan pembelajaran. Berdasarkan pendapat diatas, dapat digolongkan bahwa cita-cita dan aspirasi, kemampuan siswa dan kondisi siswa merupakan faktor intrinsik. Sedangkan kondisi lingkungan siswa, dan unsur-unsur dinamis dalam belajar dan pembelajaran, merupakan faktor ekstrinsik. Sejalan dengan pendapat Dimyati dan Mudjiono (2010:97), pada penelitian ini digunakan beberapa indikator motivasi intrinsik dan ekstrinsik diantaranya, untuk motivasi intrinsik yaitu prestari, pengakuan, kemajuan. Indikator motivasi ekstrinsik, antara lain kebijakan kelas, kondisi kelas, hubungan teman sejawat, dan hubungan antara angkatan.

Dari pembehasan diatas, dapat disimpulkan bahwa motivasi belajar pengurus harian dan anggota unit kegiatan mahasiswa (UKM) Universitas Negeri Malang tergolong dalam interval tinggi. Motivasi belajar mahasiswa tersebut dipengaruhi oleh dua jenis motivasi belajar yaitu motivasi instrinsik yang berasal dari dalam diri individu dan motivasi ekstrinsik yang berasal dari luar diri individu.

\section{Prestasi Belajar Mahasiswa}

Ada dua macam faktor yang dapat mempengaruhi prestasi belajar mahasiswa, yaitu faktor intern dan faktor ekstern (Slameto, 2010:54). Faktor intern merupakan faktyor dari dalam diri seseorang atau individu, yang terkait dengan jasmani, psikologis dan kelelahan. Faktor ekstern antara lain, keluarga, sekolah dan masyarakat. Faktor-faktor tersebut saling berinteraksi langsung dan mempengaruhi prestasi mahasiswa. Motif menjadi salah satu faktor intern (psikologi) yang turut mempengaruhi prestasi akademik peserta didik, sedangkan kematangan dan kesiapan (psikologi) yang mempengaruhi prestasi non akademik peserta didik sehingga motivasi belajar turut mempengaruhi mahasiswa untuk berprestasi. Kedua jenis faktor tersebut, yaitu intern dan ekstern saling berinteraksi dan mempunyai peran masingmasing dalam mempengaruhi prestasi akademik dan non akademik mahasiswa. Maka, kondisi diri dan jiwa serta lingkungan mahasiswa haruslah menjadi perhatian agar dia dapat berprestasi secara maksimal.

Prestasi akademik mahasiswa dalam penelitian ini menggunakan nilai Indeks Prestasi Kumulatif (IPK) yang dapat dilihat pada Kartu Hasil Studi (KHS) yang berisi keterangan nilai Indeks Prestasi (IP) tiap semester. Dari nilai IP tiap semester tersebut, kemudian dihitung nilai IPK mahasiswa yang merupakan hasil prestasi akademiknya setelah menempuh beberapa semester. Sedangkan prestasi non akademik mahasiswa dalam penelitian ini menggunakan presentase dalam menentukan tingkat lebih tinggi mahasiswa dalam meningkatkan prestasi non akademiknya.

Dari hasil analisis dan pembahasan hasil analisis data terkait motivasi belajar dan prestasi belajar akdemik dan non akademik pengurus harian dan anggota UKM diatas, diketahui bahwa motivasi belajar pengurus harian dalam interval tinggi dan prestasi akademik dalam predikat sangat memuaskan dan juga prestasi non akademik ditaraf Nasional. Sedangkan motivasi belajar anggota UKM dalam interval tinggi namun prestasi akademik dalam predikat dengan pujian dan prestasi non akademik ditaraf Nasional. Terdapat perbedaan diantara keduanya yaitu di prestasi akademik yang dimana pengurus harian dan 
anggota UKM sama-sama memiliki motivasi belajar diinterval sangat memuaskan dan prestasi non akademik sama-sama ditaraf Nasional akan tetapi prestasi akademik memiliki perbedaan, pengurus harian predikat sangat memuaskan sedangkann anggota UKM predikat dengan pujian. Alasan mengapa hal ini terjadi adalah tanggung jawab yang dimiliki oleh pengurus harian dan anggota UKM sangat berbeda dalam berorganisasi di UKM tersebut sehingga terjadi perbedaan di prestasi akademiknya. Alasan lain adanya perbedaan keaktifan dalam berorganisasi antara pengurus harian dan anggota UKM dikarenakan pengurus harian harus lebih intens dalam berorganisasi sehingga membuat prestasi akademik meraka berbeda dengan anggota UKM. Akan tetapi berorganisasi bukanlah penghambat untuk mahasiswa dalam meningkatkan pretasi belajar baik akademik maupun non akademik. Dalam hal ini faktor intrinsik dalam motivasi belajar yang timbul dari diri setiap individu harus lebih optimalkan untuk mencapai keseimbangan antara motivasi belajar dan prestasi belajar baik akademik maupun non akademik.

\section{Perbedaan Motivasi Belajar Mahasiswa yang Menjadi Pengurus Harian dan yang Menjadi Anggota UKM}

Berdasarkan hasil analisis, diketahui terdapat perbedaan yang signifikan motivasi belajar mahasiswa yang menjadi pengurus harian UKM dan yang menjadi anggota UKM. Faktor intrinsik dan faktor ekstrinsik dalam motivasi belajar sangat berpengaruh. Pada motivasi intrinsik, dorongan kebutuhan belajar mahasiswa yang menjadi pengurus harian UKM dan anggota UKM menjadi motif dan pendorongnya untuk semangat belajar. Hal ini sejalan dengan teori kebutuhan berprestasi menurut McClelland yaitu memiliki dorongan utuk melebihi, mencapai standar-standar, dan berusaha keras untuk berhasil dalam mencapai prestasi. Mahasiswa yang menjadi pengurus harian UKM dan anggota UKM sama-sama memiliki kebutuhan terkait prestasi pada tingkatan yang sama, sehingga motivasi belajarnya pun berada pada tingkat kebutuhan yang sama, Maslow dengan terori hierarki kebutuhanya, juga menyebutkan bahwa salah satu kebutuhan manusia adalah kebutuhan aktualisasi diri dan dalam penelitian ini menjadi salah satu motivasi yang menggerakkan mahasiswa untuk meraih tujuannya dan membuktikan kemampuannya. Mahasiswa yang menjadi pengurus harian UKM dan anggota UKM sama -sama memiliki kebutuhan akan aktualisasi diri, sehingga keduanya sama-sama berusaha keras untuk memenuhi kebutuhan tersebut. Pada motivasi ekstrinsik tercermin pada kondisi lingkungan, yang dalam hal ini adalah kebijakan kelas, kondisi kelas, hubungan teman sejawat, hubungan dengan unit di bawahnya, status, dan keamanan". Kebutuhan hubungan teman sejawat/kolegial dan hubungan antar angkatan, merupakan keinginan antarpersonal yang ramah dan akrab dilingkungan sekitar. Kebutuhan ini berguna dalam motif yang tinggi dalam persahabatan, menginginkan hubungan yang melibatkan dalam tingkat pengertian mutual yang tinggi, dan lebih menyukai situasi kooperatif (dibandingkan kompetitif). Adanya hubungan yang baik antara teman sejawat, akan berdampak pada kesuksesan dalam mengejar prestasi yang lebih tinggi.

\section{Perbedaan Prestasi Belajar Mahasiswa yang Menjadi Pengurus Harian UKM dan yang Menjadi Anggota UKM}

\section{Prestasi Akademik}

Berdasarkan hasil analisis, dapat dilihat bahwa tidak terdapat perbedaan yang signifikan prestasi belajar akademik mahasiswa yang menjadi pengurus harian UKM dan yang menjadi anggota UKM..

\section{Prestasi Non Akademik}

Menurut hasil analisis, dapat dilihat bahwa terdapat perbedaan yang signifikan prestasi belajar akademik mahasiswa yang menjadi pengurus harian UKM dan yang menjadi anggota UKM.

Prestasi belajar diperoleh dikarenakan terdapat faktor lain yang dapat mempengaruhi seseorang untuk berprestasi yaitu faktor intern dan ekstern (Slameto, 2010:54). Faktor intern yang ada pada diri individu itu sendiri meliputi faktor jasmani (kesehatann dan cacat tubuh), psikologi (kesepian, kematangan, motif, bakat, minat, dan integelegensi), dan kelelahan. Faktor ekstern atau faktor dari luar 
individu meliputi lingkungan keluarga (relasi antar keluarga), sekolah (relasi antar teman dan relasi dengan guru), dan masyarakat (teman bergaul). Kedua faktor tersebut memberi perannya masing-masing dalam mempengaruhi seseorang untuk berprestasi. Pada faktor intern, perbedaan intelegensi, motif dan kesiapan mahasiswa yang menjadi pengurus harian dan anggota UKM dapat menjadi penyebab perbedaan antara prestasi akademik dan prestasi non akademiknya. Pada faktor ekstern, perbedaan lingkungan teman bergaul, relasi antar teman dan guru dan relasi antar keluarga mahasiswa yang menjadi pengurus harian dan anggota UKM dapat menjadi penyebab perbedaan antara prestasi akademik dan prestasi non akademik mahasiswa.

\section{KESIMPULAN}

Berdasarkan hasil penelitian dan pembahasan yang telah diuraikan dapat diperoleh kesimpulan; (1) hasil analisis dekriptif menunjukan bahwa secara keseluruhan nilai rata-rata motivasi belajar penguruh harian termasuk dalam kualifikasi tinggi; (2) hasil analisis dekriptif menunjukan bahwa secara keseluruhan nilai rata-rata motivasi belajar anggota UKM termasuk dalam kualifikasi tinggi; (3) tingkat prestasi belajar pengurus harian; (a) tingkat prestasi belajar akademik pengurus harian dalam predikat sangat memuaskan; (b) tingkat prestasi belajar non akademik pengurus harian memiliki presentase ditingkat Nasional; (4) tingkat prestasi belajar anggota UKM; (a) tingkat prestasi belajar akademik anggota UKM dalam predikat dengan pujian; (b) tingkat prestasi belajar non akademik anggota UKM memiliki presentase ditingkat Nasional; (5) hasil analisis menunjukkan bahwa terdapat perbedaan yang signifikan motivasi belajar mahasiswa yang menjadi pengurus harian UKM dan yang menjadi anggota UKM; (6) perbedaan secara signifikan prestasi belajar pengurus harian dan anggota UKM sebagai berikut; (a) hasil analisis menunjukan tidak terdapat perbedaan yang signnifikan prestasi belajar akademik mahasiswa yang menjadi pengurus harian UKM dan yang menjadi anggota UKM. (b) hasil analisis menunjukkan terdapat perbedaan yang signnifikan prestasi belajar non akademik mahasiswa yang menjadi pengurus harian UKM dan yang menjadi anggota UKM.

\section{DAFTAR RUJUKAN}

Basori, H.M. 2016. Hubungan Antara Keaktifan Mahasiswa Dalam Organisasi Kemahasiswaan Dan Motivasi Belajar Dengan Prestasi Belajar Mahasiswa Pendidikan Ips Fis Uny. (online), No. 7-8.

Dimyati, M. \& Mujiono. 2002. Belajar dan Pembelajaran. Jakarta: Rineka Cipta.

Hermit, H. 2007. Fun di Kampus Impian: Kiat-kiat belajar Efektif dan Menyenangkan di Perguruan Tinggi. Bandung: PT Remaja Rosdakarya.

McClelland, D.C. 1987. Human Motivation. New York: Cambridge University Press.

Nawawi, H. 2001. Manajemen Sumber Daya Manusia . Jakarta: Gadja Mada University Press.

Sadirman. 2011. Interaksi dan Motivasi Belajar Mengajar. Jakarta: PT Raja Grafindo Persada.

Slameto. 2010. Belajar dan Faktor-faktor yang Mempengaruhi. Jakarta: Renika Alfabet.

Sunarto. 2012. Pengertian Prestasi Belajar. Fasilitator idola (online). http://sunartombs.wordpress. com/2009/01/05pengertian-prestasi-belajar/. 27 Februari 2017.

Syah, M. 2004. Psikologi Pendidikan dengan Pendekatan Baru. Bandung: PT Remaja Rosda Karya.

Winardi, J. 2002. Motivasi dan Pemotivasian dalam Manajemen. Jakarta: Raja Grafindo Persada. 